\title{
Reading in L2 (English) and L1 (Persian): An Investigation into Reveres Transfer of Reading Strategies
}

\author{
Seyed Hassan Talebi \\ English language and Literature Department, Faculty of Humanities and social sciences \\ Main Campus of the University (Pardis), University of Mazandaran, Iran \\ Tel: 98-911-218-7707Ｅ-mail: talebi4@gmail.com
}

Received: November 20, 2011

Accepted: December 28, 2011

Published: March 1, 2012

doi:10.5539/elt.v5n3p217

URL: http://dx.doi.org/10.5539/elt.v5n3p217

\begin{abstract}
This study investigates the effect of reading strategies instruction in $\mathrm{L}_{2}$ (English) on raising reading strategies awareness and use and reading ability of Iranian EFL learners in $\mathrm{L}_{2}$ (English) and L1 (Persian) as a result of transfer of reading strategies from L2 to L1. To this purpose, 120 students of intermediate and advanced English proficiency levels constituted the control and experimental groups. Then, a test of reading comprehension and a reading strategy questionnaire in $\mathrm{L}_{2}$ and $\mathrm{L}_{1}$ as pretests were distributed to the participants. After giving the experimental groups reading strategy instruction the post tests were distributed to all participants. Analysis of the data showed the experimental group outperformed the control group on the English and Persian reading comprehension strategy questionnaire and reading comprehension tests. Through teaching reading strategies in $\mathrm{L}_{2}$ we can enhance the reading strategy awareness and use and reading ability of EFL students both in $\mathrm{L}_{2}$ and $\mathrm{L}_{1}$.
\end{abstract}

Keywords: Reading, Reading strategies, Reverse transfer, First language, Second language

\section{Introduction}

Reading, whether in $\mathrm{L}_{1}$ or $\mathrm{L}_{2}$ is surely an important skill. Chastain $(1988$, p. 216) states "reading is a basic and complementary skill in language learning." Since reading is a problem-solving activity, the idea of strategic reading has become the matter of investigation in recent years. Since the late 1970's, ESL researchers have begun to recognize the relationship between reading strategies and successful and unsuccessful second language reading in L1 and/or L2 (Block, 1986; Jimenez, Garcia, and Pearson, 1995, Anderson and Roit, 1993; Block, 1993; Palincsar and Brown, 1984; Paris, Cross, and Lipson, 1984; Pearson and Fielding, 1991, Carrell, 1998). Urquhart and Weir (1998, p. 95) regard reading strategies as "ways of getting around difficulties encountered while reading." Reading in a $\mathrm{L}_{2}$ is not a monolingual event. $\mathrm{L}_{2}$ readers have access to their first language as they read. The influence of the L1 on the learner's performance in a given target language is called "substratum transfer" (Odlin, 1989, p. 169). Odlin (1989, p. 27) defines transfer as "the influence resulting from similarities and differences between the target language and any other language (emphasis added) that has been previously (and perhaps imperfectly) acquired." This transfer can affect all linguistic (such as phonetic, phonological, semantic, syntactic, morphological) and non-linguistic (such as concepts, culture, and attitude,) levels. Cohen (1995) found that people with access to two or more languages frequently shift between them. Pavlenko and Travis (2002, p. 191) in their discussions of transfer, refer to 'bidirectional transfer' as the two-way interaction between the two linguistic systems. As far as the bi-directional transfer is concerned, the concept of "dual language" was put forward as an alternative to "interlanguage" (Kecskes \& Papp, 2003; Kecskes \& Cuenca, 2005). Research in language studies has ever used terms such as $\mathrm{L}_{1}$ and interlanguage (Selinker, 1972). Interlanguage is the language of the $\mathrm{L}_{2}$ learner as an approximation to an $\mathrm{L}_{1}$ system of native speakers. However, Cook $(2003, \mathrm{p}$.1) introduces these concepts in a more comprehensive way by using the term 'multicompetence'. Multi-competence means the knowledge of two or more languages in one mind. It involves the concept of interlanguage and $\mathrm{L}_{1}$, and regards the mind of the $\mathrm{L}_{2}$ user with these components as a whole rather than as separate components. As Cook $(2004$, p. 2) states, this concept suggests that "since the first language and the other language or languages are in the same mind, they must form a language super-system at some level rather than completely separate systems." Therefore, studying second language acquisition means accepting this totality, not just the interlanguage component. Grosjean (1992, in Pavlenko \& Travis, 2002) states that a bilingual is not the sum of two complete or incomplete monolinguals in one body but rather a specific speaker with a unique linguistic system.

The idea of multi-competence opens a new area of research on the effects of $\mathrm{L}_{2}$ on L1. Lu (2004) notes, "language 
transfer is not restricted to L1 transfer." The direction of this transfer may also be the reverse. This kind of transfer is referred to as "borrowing transfer" (Odlin, 1989, p. 169), reverse or backward transfer (see Kecskes \& Papp, 2000). Borrowing transfer affects language in all its aspects; "although the L1's phonetic and phonological features are not likely to be affected, since it is so established in the speaker" (Arranz, 2005, p. 117). Cook (2003, p. 1) mentions that "the first language of people who know other languages differs from their monolingual peers in diverse ways" from vocabulary to pragmatics. Bialystok (2001) maintains that L2 user children have more metalinguistic skills in L1 than their monolingual peers. Hungarian children who know English use more complex sentences in their L1 than those who do not know English (Kecskes \& Papp, 2000).

Cook (2004, p. 1) states "learning another language does seem to change people's 'thinking' to some extent." With all that has been mentioned above about the benefits of knowing a second language and the cross-linguistic influence, it seems that not much research has been carried out on the effects of $L_{2}$ on $L_{1}$ as far as the transfer of reading strategies from $\mathrm{L}_{2}$ to $\mathrm{L}_{1}$ is concerned. This study attempts to investigate if the reading strategy awareness and use and reading ability in $\mathrm{L}_{2}$ would transfer to $\mathrm{L}_{1}$ reading tasks as a result of explicit reading strategy instruction in $\mathrm{L}_{2}$. The following hypotheses are therefore put forward:

1a \& b) There is no differential gain for experimental and control groups in English/Persian reading scores after the intervention;

$2 \mathrm{a} \& \mathrm{~b}$ ) The proficiency level of students will have no significant influence over gain in scores from pre to post test situation in English/Persian reading scores;

$3 a \& b)$ There is no differential gain for experimental and control groups in English/Persian reading strategy scores after the intervention;

4a \& b) The proficiency level of students will have no significant influence over gain in scores from pre to post test situation in English/Persian reading strategy scores.

\section{Methodology}

\subsection{Participants}

The subjects of this study were Iranian pre-university boy students of about 18 years of age, who had already passed the general English as well as the Persian language and literature courses at the third grade of high school.

\subsection{Instrumentation}

The following instruments were used in this study:

\subsubsection{Language Proficiency Test}

In order to make sure of the homogeneity of the control and experimental groups in terms of their English language knowledge, a test battery of Nelson, series 400B was employed. The time allotted was 30 minutes. The test was piloted on a similar group of ten students and the reliability of the test scores according to the KR-21 formula turned out to be 75.78 .

\subsubsection{Test of Reading Comprehension in English}

In developing the test of reading comprehension in English five passages were selected from the reading section of books two and three of New Interchange series (Richards, 1997). The number of words in the selected five passages ranges from 257 to 295 words. Six items were developed for each passage and in all there were thirty items for all five passages. The nature of the items in terms of recognizing main ideas, vocabulary knowledge, and inferencing was the same for all passages. The reliability of the test of reading as calculated through the K-R 21 formula turned out to be .81 . To determine the concurrent validity of the test of reading in English, the correlation coefficient between the Nelson test of proficiency in English and the test of reading comprehension in English in the piloting stage was calculated and turned out to be .79 . The time allowed was 30 minutes as determined at the piloting stage.

\subsubsection{Test of Reading Comprehension in Persian language}

The reading comprehension test in Persian had two passages, each containing fifteen items, and in all 30 items. The nature of the items for the two passages in terms of recognizing main ideas, vocabulary knowledge, and inferencing was the same. After administering this test to a similar group of twenty students, the reliability of the scores of this test according to the KR-21 formula at the piloting stage was calculated to be 0.82 .

\subsubsection{Questionnaire}

The strategic approach was measured by means of a five-point Likert scale reading strategies questionnaire (Never/ Seldom/ Sometimes/ Usually/ and Always true of me) offering an immediate retrospective picture of the reading 
behavior.. All the 33 items in this study were adapted from different related questionnaires in research-validated studies (Oxford, R, L., Yunkyoung Cho, Santoi Leung, and Hae-Jin Kim, 2004; Sheorey R. and Mokhtari, K., 2001; Baker, William and Boonkit, Kamonpan, 2004; Taillefer and pugh, 1998) and adopted for the purpose of this study. The reason why these items were selected was the ease of use by students, ease of training to the students in the experimental group as far as the time limit was concerned, and finally being of great importance in reading both in $\mathrm{L}_{2}$ and $\mathrm{L}_{1}$. The strategy questionnaire was in Persian so that students felt more comfortable with the questionnaire. The internal consistency reliability coefficient of the instrument at the piloting stage was calculated to be 0.78 as it was piloted with 10 students of the similar proficiency level taking part in the study.

\subsection{Procedure}

First the Nelson English language proficiency test was administered to 198 students through which two groups were identified, that is, those whose scores were between -1 and +1 Standard deviation on the normal distribution curve (i.e., 35.65- 60.65) were taken as intermediate and those whose scores were above +1 Standard deviation (i.e., 60.65 and above) as advanced group. The selected subjects were then put into control and experimental groups, each containing 30 students. To find out the current reading ability of subjects in $\mathrm{L}_{2}$ reading comprehension, the English language reading test as a pretest was administered among the subjects, which was immediately followed by the reading strategy questionnaire as a retrospective measure of their strategic reading behavior. This would determine what strategies students applied before, during, and after reading in their $\mathrm{L}_{2}$. In the next session (the students had two sessions a week) the reading test in Persian was administered as another pretest, followed by the same reading strategy questionnaire to determine what strategies students would use before, while and after reading in Persian. After the pretest, the experimental group received strategy treatment along with their regular classroom materials, but the control group was only taught their regular classroom materials.

Students should experience successful learning and develop independent learning skills with the support of the teacher. This process has been referred to as 'scaffolding'. Gradually, the teacher removes the supports, so that students can practice independently (Jones et al., 1987). In this study for the scaffolding of the reading process the two central phases of Scaffolding Reading Experience (SRE) (Graves and Graves, 1994, in Graves and Graves, 1995) were used as given below:

a) The planning phase: In the planning phase the teacher should consider the students (their needs, concerns, interests, strengths, weaknesses, background knowledge, etc.), the text (its topic and theme, it comprehensibility, etc), and the purpose(s) for reading (for what purpose is the student reading the text?); and,

b) The implementation phase: The implementation phase of SRE has three components: pre-reading, during reading, and post-reading activities.

Apart from this, in this study three types of scaffolding as mentioned in McEwan (2004) were used as given below:

1) People (teacher and peers) scaffolding: for this purpose the model of Collaborative Strategic Reading (CSR) developed by Klingner and Vaughn $(1996,1998)$ was adopted and adapted. Klingner and Vaughn (1996) designed CSR by combining reciprocal teaching (Palincsar and Brown, 1984) with cooperative learning (Johnson and Johnson, 1987). Through a number of research trials, CSR has been refined and currently consists of four comprehension strategies that students apply before, during, and after reading in small cooperative groups. These reading strategies are:

(a) preview (before reading); (b) click and clunk (during reading); (c) get the gist (during reading); and, (d) wrap-up (after reading).

It was selected for the following reasons: 1) It integrates oral language development and reading through all phases of instruction; 2) it develops critical thinking and social skills; 3) it develops self-esteem and self-confidence; 4) it helps students develop proficiency in English; and, 5) it can be applied in the three phases of pre-reading, while-reading, and post-reading activities.

Initially, the teacher presents the strategies (preview, click and clunk, get the gist, and wrap-up) to the whole class using modeling and the thinking aloud techniques. The goals of CSR are to improve reading comprehension and increase conceptual learning in ways that maximize students' involvement. CSR was implemented in two phases: a) teaching the strategies, and, b) cooperative learning group activity or student pairing.

However, in people scaffolding three stages of $\boldsymbol{I}$ do it, We do it, and You do it, are implemented each of which will be explained below:

a: I do it, in which the teacher models the strategy by thinking aloud for students. Here the first phase of CSR, that is Teaching the Strategies, was applied. I explained each single strategy employed in the study. The strategy training 
consists of a number of pre-reading, while-reading and post-reading strategies.

In this study the five strategy instruction elements by Winograd and Hare (1988, in Carrell, 1998) were employed, including a) What is the strategy? b) Why should a strategy be learned? c) How should a strategy be used? d) When and where should the strategy be used? And, e) How should a strategy use be evaluated?

A common method of teaching strategies is the teacher think-aloud method or modeling (see Pressley, El-Dinary, and Brown, 1992, p. 112) which is "the act of thinking aloud regarding cognitive processing as well as engaging in observable behaviors" (McEwan, 2004, p. 21). For example, a teacher can model comprehension monitoring while reading aloud to the students by saying I understand this paragraph, so I will go on, or This paragraph doesn't make sense; I'd better reread it.

The teacher and students had a text in hand. The teacher read the text by using the think-aloud technique and showed the students how to deal with the text strategically. To this end, the first phase of CSR (i.e., Teaching the Strategies) was employed. Students learn four strategies of previewing (pre-reading), click and clunk, and getting the gist (while-reading), and wrapping up (post-reading) through teacher modeling. I got the text and began to think aloud about the preview section. I asked myself questions such as Do I know anything about the topic? Do the pictures, graphs, diagrams, etc. give me a hint of the text content? What is the main idea? Then, I began to think aloud about the answer to these questions. In Klingner and Vaughn's CSR model there were two key activities for the preview stage (i.e., activating background knowledge and predicting about the text). However, the preview strategy is supported by the pre-reading strategies as fix-up strategies in order for CSR to suit the purposes of this study.

After finishing the preview stage I began to think aloud about the text using the while reading Click and Clunk strategy as mentioned in CSR. The click is something that readers understand while reading. The clunk is something that they don't understand. Click and clunk is a strategy used to monitor one's understanding during reading, and to use fix-up strategies when failure to understanding occurs. To think aloud I read a paragraph aloud and asked myself Is everything clicking? Where are the clunks in the section that I am just reading? I then used fix-up strategies to figure out the clunks.

Another while reading strategy according to Klingner and Vaughn's CSR model is Get the Gist. Get the Gist is employed for each paragraph. I began to think aloud using this strategy by asking myself questions about the most important person, place, or thing in the paragraph I was reading. Then I tried to find the answer for my questions.

However, the click and clunk, and get the gist strategies are supported by the while-reading strategies as fix-up strategies in order for CSR to suit the purposes of this study.

After finishing the preview, click and clunk and get the gist strategies I began to think aloud about the text using the post reading wrap up strategy as is mentioned in CSR. Wrap-up consists of two activities: a) generating questions, and b) reviewing. I began thinking aloud using questions mainly starting with who, what, when, where, why, and how. Then, I tried to find out the answers to my questions. I went through the text to re-read the difficult parts or find out more about the details. Then, the wrap up strategy was supported using the post reading strategies as fix-up strategies.

After students have witnessed applying the strategies through teacher modeling, the teacher asks them to form groups of five students, where each student performs a defined role as students collaboratively implement the strategies. This comes in the following We do it stage.

b: We do it, in which the class is divided into cooperative groups to practice pre-reading, while-reading and post-reading strategies together with supportive instruction from the teacher or the whole class working together with the teacher in guided practice using the CSR. Cooperative learning is "any pattern of classroom organization that allows students to work together to achieve their individual goals" (Harris and Hodges, 1995, in Koda, 2005, p. 267). For the We do it stage, we once again refer to the three strategies of previewing, click and clunk, and getting the gist.

Once students have learned the four strategies (preview, click and clunk, get the gist, and wrap up) and the related support strategies through teacher modeling, they are asked to apply CSR in their peer-led cooperative learning groups. Student roles are an important aspect of CSR. Members have been assigned reading tasks. Procedures for having cooperative learning groups are as follows.

Set the stage. First, I randomly assigned students to groups of five. The group members would change every two or three sessions. Then, I assigned roles to students. I changed their roles on a regular basis so that students can experience a variety of roles. The following five roles were given to the five members of the group:

1) Leader: Tells the group what to read and what strategy (Pre-, While-, Post- reading strategy) to use. 
2) Clunk Expert: Reminds the group of the steps to follow when trying to figure out the clunk(s).

3) Gist Expert: Guides the group toward getting the gist and determines that the gist contains the most important idea(s) but not unnecessary details.

4) Announcer: Calls on group members to read a passage or share an idea.

5) Reporter: Reports to the class the main ideas the group learned and shares a favorite question the group has generated.

And now we will have a look at the role of each cooperative group members in this study in the three stages of pre-, while-, and post-reading strategies.

\section{Preview: (before reading)}

Leader: We know that today's topic is-------------. Let's brainstorm about the topic.

Leader: now have a quick look at the whole text and use support preview strategies.

Announcer: Now we share our best ideas. You (for example, student number one) first say what you think of the topic.

Gist expert: Have you got the general idea of the text through skimming? Tell about it.

Clunk expert: Have you used the support preview strategies to have a better understanding of the whole text? What are the questions that you might want to answer while you are reading the text.

Leader: Now, let's predict and write everything we think we might learn about from reading today.

Reporter: I would like to report to other groups our predictions about the text and the main ideas we learnt in the preview. I will also raise the questions that we expect to find answers for in the during-reading activity.

\section{Click and clunk and Get the Gist (During reading)}

Leader: Now we will read each paragraph one by one and use support Click and Clunk and Get the Gist strategies.

Announcer: someone please read. Student number one you read please.

Gist expert: Now we will go around the group and each will give the gist in his own words.

Gist expert: What is the most important idea in this paragraph?

Clunk expert: Tell us where your clunk in this paragraph was. Have you tried to use the support while-reading strategies? Other members please help him how to find out the clunks using fix-up strategies.

Reporter: our group's understanding of this paragraph is this. We still have some clunks. What is your idea about our clunks? How can we figure them out?

\section{Wrap up (After reading)}

Leader: Let's have a review of what we covered in the text. Please share your whole understanding of the text and use support wrap-up strategies.

Leader: Now, let's think of some questions to check if we really understood what we read. Please make as many questions as you can about the text you read. Try to start your questions mainly with who, when, what, where, why, or how.

Announcer: Please share your best questions. Student number one what are your questions? The rest please try to answer the questions and share your answers.

Clunk expert: For some of us there are some difficult questions. Why do you think you could not answer them? Did you go back to read the details of the passage to find the answer of some questions? Others please help him how to find the answer if he cannot get the answer himself.

Reporter: I would like to retell our understanding and our possible clunks of the whole text to other groups and then to figure our clunks out.

During the cooperative group activity, my role as a teacher was to circulate among the groups to encourage students to remain on-task and provide assistance.

c: You do it, in which the students are expected to use strategies more independently still by teacher's supportive scaffolding. Again some reading tasks were given to each student and they were asked to read and think-aloud about it for themselves using the three support preview, click and clunk and get the gist strategies. They were also asked to answer the end of the text questions. 
2) Text scaffolding: Texts of reasonable reading difficulty and high interest to students were used to make strategy instruction less threatening and confusing for students. The reading materials had themes and supporting details and consisted of several paragraphs. They also contained clues/pictures for predicting.

3) Task scaffolding: Learners were offered a range of possible reading tasks to help them deploy and transfer the strategies. Transfer is enhanced by task similarity. The probability of transfer from one task to another is increased on a new task when the new task is similar to a previous task (Ross, 1987), and the learner understands the conditions under which the strategy applies (Pressley, Levin, and Ghatala, 1984a). Then I told the students that in the real activity of reading they must employ all the strategies together depending on the kind of text and tasks demands.

The course consisted of sixteen sessions of 70 minutes. The strategy instruction was carried out by the researcher himself arranged with the normal class hour. After the treatment was over, both the Experimental and Control groups were given the posttests.

\section{Results and Discussion}

Independent samples ' $t$ ' test and repeated measure ANOVA were employed to compare the mean scores of the intermediate and advanced students from the control and experimental groups on the pretest and post test Farsi and English reading strategies questionnaire and reading comprehension test.

As represented in Table 1, the Repeated Measure ANOVA revealed that there was a significant change in the English reading scores from pre to post test situation irrespective of the groups. F value of 309.215 was found to be significant at .000 levels. From the mean values it is evident in the pre test irrespective of the groups the mean score was 14.77 which was increased to 16.09 with the gain of 2.32 scores. However, when the change of scores from pre to post test situation was considered with respect to groups, again a significant $F$ value was observed ( $\mathrm{F}=286.318$; $\mathrm{P}<.000$ ) indicating a differential gain for groups. From the table we find that experimental group had a gain of 2.60 scores (From 15.05 to 17.65) whereas the control group had a gain of only .05 scores (from 14.48 to 14.53). We can definitely say that experimental group which had undergone intervention of reading strategies instructions had gained better than control group, which had not undergone such intervention. (See Table 1)

Hence, hypothesis 1a formulated as "There is no differential gain for experimental and control groups in English reading scores after the intervention" is rejected as the experimental group gained significantly higher than the control group.

As represented in Table 2, in Persian reading test, repeated measure ANOVA revealed that there was a significant change in scores from pre to post test situation irrespective of the groups. F value of 504.903 was found to be significant at .000 level. From the mean values it is evident in the pre test irrespective of the groups the mean score was 15.23 which was increased to 17.23 with the gain of 1.45 scores. However, when the change of scores from pre to post test situation was considered with respect to groups, again a significant $F$ value was observed $(F=438.034$; $\mathrm{P}<.000$ ) indicating a differential gain for groups. From the table we find that the experimental group had a gain of 2.81 scores (From 15.87 to 18.68 ) whereas the control group had a gain of only .10 scores (from 15.68 to 15.78). We can definitely say that the experimental group which had undergone intervention of reading strategy instructions had gained better than the control group, which had not undergone such intervention. (See Table 2)

Hypothesis $1 \mathrm{~b}$ formulated as "Proficiency level of students will not have any significant influence over gain in scores from pre to post test situation in English reading scores" is accepted as there was no significant $\mathrm{F}$ value observed.

Further, gains with proficiency as well as gains with proficiency and groups were both found to be non-significant indicating that proficiency level of students did not influence the performance from pre to post test situation in English. (See Table 3)

Therefore, hypothesis 2a formulated as "There is no differential gain for experimental and control groups in Persian reading scores after the intervention" is rejected as the experimental group gained significantly higher than the control group.

Further, gains with proficiency as well as gains with proficiency and groups were both found to be non-significant indicating that proficiency level of students did not influence the performance from pre to post test situation in Persian. (See Table 4)

Hypothesis $2 b$ formulated as "Proficiency level of students will not have any significant influence over gain in scores from pre to post test situation in Persian reading scores" is accepted as there was no significant F value observed. 
As shown in table 5, Repeated Measure ANOVA revealed that there was a significant change in scores from pre to post test situation in English strateg questionnaire scores irrespective of the groups. F value of 3337.064 was found to be significant at .000 level. From the mean values it is evident in the pre test irrespective of the groups the mean score was 44.39 which was increased to 77.04 with the gain of 32.65 scores. However, when the change of scores from pre to post test situation was considered with respect to groups, again a highly significant $\mathrm{F}$ value was observed $(\mathrm{F}=2921.599 ; \mathrm{P}<.000)$ indicating a differential gain for groups. From the table we find that experimental group had a gain of 63.20 scores (from 44.92 to 108.12) whereas the control group had a gain of only 2.10 scores (from 43.87 to 45.97). We can definitely say that experimental group which had undergone intervention of reading strategy instructions had gained better than control group, which had not undergone such intervention. (See Table 5)

Thus, hypothesis 3a formulated as "There is no differential gain for experimental and control groups in English reading strategy scores after the intervention" is rejected as the experimental group gained significantly higher than the control group.

As Table 6 represents, Repeated measure ANOVA revealed that there was a significant change in scores from pre to post test situation in Persian reading strategy scores irrespective of the groups. F value of 3872.278 was found to be significant at .000 level. From the mean values it is evident in the pre test irrespective of the groups the mean score was 46.38 which was increased to 76.72 with the gain of 30.34 scores. However, when the change of scores from pre to post test situation was considered with respect to groups, again a highly significant $F$ value was observed $(\mathrm{F}=3418.346 ; \mathrm{P}<.000)$ indicating a differential gain for groups. From the table we find that the experimental group had a gain of 30.34 scores (from 46.38 to 76.72 ) whereas the control group had a gain of only 1.83 scores (from 47.20 to 49.03 ). We can definitely say that the experimental group which had undergone intervention of reading strategy instructions had gained better than control group, which had not undergone such intervention.

Hypothesis verification indicated that hypothesis $3 b$ formulated as "There is no differential gain for experimental and control groups in Persian reading strategies questionnaire scores after the intervention" is rejected as experimental group gained significantly higher than control group.

Further, gains with proficiency as well as gains with proficiency and groups were both found to be non-significant indicating that proficiency level of students did not influence the performance from pre to post test situation. (See Table 7)

Hypothesis 4a formulated as "Proficiency level of students will not have any significant influence over gain in scores from pre to post test situation in English reading strategy scores" is accepted as there was no significant F value observed.

Further, gains with proficiency as well as gains with proficiency and groups were both found to be non-significant indicating that proficiency level of students did not influence the performance from pre to post test situation. (See Table 8)

Hypothesis $4 \mathrm{~b}$ formulated as "Proficiency level of students will not have any significant influence over gain in scores from pre to post test situation in Persian reading strategy scores" is accepted as there was no significant $\mathrm{F}$ value observed.

\section{Conclusion and Implication}

Strategy instruction to learners has shown mixed results. Studies in $\mathrm{L}_{1}$ and $\mathrm{L}_{2}$ showed that reading strategy instruction can help poor readers improve their reading comprehension (Carrell, 1985; Anderson and Roit, 1993; Block, 1993; Palincsar and Brown, 1984; Jimenez et al. 1995; Pearson and Fielding, 1991). The finding of the current study about the effect of reading strategy instruction in $\mathrm{L}_{2}$ on $\mathrm{L}_{2}$ reading comprehension ability and the awareness and use of reading strategies in L2 is in line with the results of these studies. However, Cotterall (1990) reported no significant improvement in the reading comprehension of ESL pre-university students after implementing reciprocal teaching intervention. The reason may be that strategies were taught to students only in $\mathrm{L}_{2}$ and no explanation was given in $\mathrm{L}_{1}$ to nullify the possible lack of understanding of the strategies in $\mathrm{L}_{2}$. This study has also shown that an increase in $\mathrm{L}_{2}$ reading ability, and reading strategy awareness and use will result in an increase in $\mathrm{L}_{1}$ reading ability, and reading strategy awareness and use as a result of transfer of reading strategies from $L_{2}$ to $L_{1}$. This finding supports the results of the following studies. Hardin (2001) found that bilingual Spanish-English fourth graders of four levels of proficiency, who were exposed to think-aloud procedures, transferred strategic behaviors from one language to the other regardless of their proficiency level. Hua (1997, in Koda, 2005) compared strategy use among Chinese ESL learners in their $\mathrm{L}_{1}$ and $\mathrm{L}_{2}$ and found that readers used identical comprehension strategies in their two languages, suggesting that reading strategies may transfer across languages, regardless of linguistic distance. Jimenez et al. (1995) also found that bilingual readers tended to have a 
unitary view of reading and conceive many similarities between reading in Spanish $\left(\mathrm{L}_{1}\right)$ and English $\left(\mathrm{L}_{2}\right)$. Sarig (1987) stated, "reading is reading" and that $\mathrm{L}_{1}$ reading strategies transfer to the $\mathrm{L}_{2}$ context. In addition, the common underlying proficiency hypothesis and the reading universal hypothesis claim that reading is a skill interdependent or universal across languages. However, the direction of the transfer in these studies was mainly from $\mathrm{L}_{1}$ to $\mathrm{L}_{2}$. In this study, the direction of transfer was from $L_{2}$ to $L_{1}$, called reverse transfer (Cook, 2003, p.1) showing the difference of the findings of this study with the aforementioned studies. Cook (2002b) points out that one of the characteristics of $\mathrm{L}_{2}$ users is that the knowledge of their $\mathrm{L}_{1}$ is in some respects not the same as that of a monolingual. In other words, the $\mathrm{L}_{2}$ user's knowledge of their first language is undoubtedly influenced by the other languages they learn, in terms of syntax, lexicon, pragmatics, phonology, etc. Diaz (1985) also found that children learning a second language have better conceptual development, creativity and analogical reasoning.

In this study the proficiency level of students did not have any significant influence over gain in scores from pre to post test situation in L2 and L1 reading tests as well as English and Persian reading strategies questionnaire. In fact, students from both proficiency levels of intermediate and advanced gained nearly the same degree of improvement as a result of the instruction of reading strategies. Available research also shows that strategy instruction positively affects both reading performance and strategy use of language learners of varying abilities (Anderson, 1991; Muniz-Swicegood, 1994; Jimenez, 1997, in Lawrence, 2007). Hua (1997, in Koda, 2005) compared strategy use among Chinese ESL learners in their $\mathrm{L}_{1}$ and $\mathrm{L}_{2}$ and found that readers used identical comprehension strategies in their two languages, suggesting that reading strategies may transfer across languages, regardless of linguistic distance. Hardin (2001) found that bilingual Spanish-English fourth graders of four levels of proficiency, who were exposed to think-aloud procedures, transferred strategic behaviors from one language to the other regardless of their proficiency level.

Learning strategy-based instruction is a learner-focused approach to teaching with the goal of creating greater learner autonomy and increased proficiency. It helps students to become more aware of available strategies, to understand how to organize and use strategies systematically and effectively, and to learn when and how to transfer strategies to new contexts (Brown, 2001). Pedagogically, it is implied that since languages are in interaction and have effects on each other, we can reach multiple goals by learning a further language. That is, to broaden the horizon of our knowledge by learning a L2, and to compensate for areas of weaknesses in L1 as a result of the transfer of knowledge from L2 to L1. Therefore, our students would be cognitively and conceptually developed both in L2, in which they receive the instruction, and L1, to which transfer of knowledge and concepts from L2 to L1 happens. It is the job of L2 teachers to make sure if their learners are aware of their own repertoire of learning strategies in L1 and L2, and if not to teach the strategies in L2 to reach two goals: improvements in strategic learning both in L2 and in L1.

\section{References}

Anderson, N. J. (1991). Individual differences in strategy use in second language reading and testing. Modern Language Journal, 75, 460-472. http://dx.doi.org/10.1111/j.1540-4781.1991.tb05384.x

Anderson, V., \& Roit, M. (1993). Planning and implementing collaborative strategy instruction for delayed readers in grades 6-10. The Elementary School Journal, 94, 121-137

Arranz, J. A (2005). Towards a global view of the transfer phenomenon. The Reading Matrix, 5(2).

Baker, William, \& Boonkit, Kamonpan, Boonkit. (2004). Learning strategies in reading and writing: EAP contexts. RELC Journal, 35(3), 299-328. http://dx.doi.org/10.1177/0033688205052143

Bialystok, E. (2001). Bilingualism in Development. Cambridge University Press.

Block, E. (1986). The comprehension strategies of second language readers. TESOL Quarterly, 20, 163-494

Block, C. C. (1993). Strategy instruction in a literature-based program. Elementary School Journal, 94, 139-151. http://dx.doi.org/10.1086/461756

Brown, H. D. (2001). Teaching by principles: an interactive approach to language pedagogy $\left(2^{\text {nd }}\right.$ Ed.). White Plains, NY: Addison Wesley Longman.

Carrell, P. L. (1985). Facilitating ESL reading by teaching text structure. TESOL Quarterly, 19(4), 727752

Carrell, P. L. (1998). Can reading strategies be successfully taught? [Online] Available: http://jalt-publications.org/old_tlt/files/98/mar/carrell.html (August, 11, 2011)

Chamot, A. U. (2005). Language Learning Strategy Instruction: Current Issues and Research. Annual Review of Applied Linguistics, 25, 112-130 
Chastain, K. (1988). Developing second language skills: Theory to Practice (3 ${ }^{\text {rd }}$ ed.). San Diego, CA Harcourt, Brace, Jovanovich.

Cohen. A. D. (1995). In which language do/should multilinguals think? Language, Culture, and Curriculum, 8, 99-113

Cook, Vivian. (2003). Changing the first language in the $\mathrm{L}_{2}$ user's mind. Draft of Intro to $\mathrm{L}_{2}$ effects on the $\mathrm{L}_{1}$. [Online] Available: http://homepage.ntlworld.com/vivian.c/Writings/Papers/FXintro.htm (August 2011)

Cook, Vivian (2004). Bilingual cognition and language teaching. Draft of paper for talk in Taiwan. [Online] Available: http://homepage.ntlworld.com/vivian.c/Writings/Papers/BilCog\&Teaching.htm (August 2011)

Cotterall, S. (1990). Developing reading strategies through small group interaction. RELC Journal, 21(2), 55-59. http://dx.doi.org/10.1177/003368829002100205

Diaz, R. M. (1985). The intellectual power of bilingualism. Quarterly Newsletter of the Laboratory of Comparative Human Cognition, 7(1), 16-22

Graves, M. F., \& Graves, B. B. (1994). Scaffolding reading experiences: Designs for students'success. Norwood, MA: Christopher Gordon.

Graves, M. F., \& Graves, B. B. (1995). The scaffolded reading experience: A flexible framework for helping students get the most out of text. Reading, 29(1)

Hardin, V. (2001). Transfer and variation in cognitive reading strategies of Latina fourth-grade students in a late-exit program. Bilingual Research Journal, 25(4), 1-21

Harris, T. L., \& Hodges, R. E. (Eds.). (1995). The literacy dictionary: The vocabulary of reading and writing. Newark, DE: International Reading Association.

Hua, T. (1997). The relationship between reading comprehension processes in $\mathrm{L}_{1}$ and $\mathrm{L}_{2}$. Reading Psychology, 18, 249-301

Jimenez, R. T. (1997). The strategic reading abilities and potential of five low-literacy Latina/o readers in middle school. Reading Research Quarterly, 32, 224-243. http://dx.doi.org/10.1598/RRQ.32.3.1

Jimenez, R., Garcia, G., \& Pearson, P. (1995). Three children, two languages, and strategic reading: Case studies in bilingual/monolingual reading. American Educational Research Journal, 32, 67-97

Johnson, D. W., \& Johnson, R. T. (1987). Learning together and alone (2 ${ }^{\text {nd }}$ Ed.). Englewood Cliffs, NJ: Prentice-Hall.

Jones, B., Palinscar, A., Ogle, D., \& Carr, E. (1987). Startegic teaching and learning: Cognitive instruction in the current areas. Alexandria Va.: Association for supervision and curriculum development.

Kecskes, I., \& Papp, T. (2000). Foreign language and mother tongue. Hillsdale, NJ: Lawrence Erlbaum.

Kecskes, I., \& I. M. Cuenca (2005). Lexical choice as a reflection of conceptual fluency. International Journal of Bilingualism, 9(1), 49-69

Klingner, J. K., \& Vaughn, S. (1996). Reciprocal teaching of reading comprehension strategies for students with learning disabilities who use English as a second language, Elementary School Journal, 96(3), 275-293. http://dx.doi.org/10.1086/461828

Klingner, J. K., \& Vaughn, S. (1998). Using collaborative strategic reading. Teaching exceptional children, 30(6), 32-37. [Online] Available: http://www.dldcec.org/pdf/teaching_how-tos/using_collaborative.pdf (August 2011)

Koda, K. (2005). Insights into second language reading: A cross-linguistic approach. Cambridge. Cambridge University Press.

Lu, Xiaofei. (2004). Promoting learner awareness of language transfer errors in ICALL. The Proceedings of the 6th International Symposium on Applied Linguistics and Language Teaching (ISALLT-04) (pp. 521-530). Beijing-Shanghai, China.

Lawrence, L. J. (2007). Cognitive and metacognitive reading strategies revisited: implications for instruction. The reading matrix, 7(3), 55-71

McEvan, E. K (2004). Seven strategies of highly effective readers. Using cognitive research to boost K-8 achievement. Corwin press.

Muniz-Swicegood, M. (1994). The effects of metacognitive reading strategy training on the reading performance and student reading analysis strategies of third grade bilingual students. Bilingual Research Journal, 18(1), 83-97 
Odlin, T. (1989). Language transfer. Cambridge University Press.

Oxford, R, L., Yunkyoung Cho, Santoi Leung, \& Hae-Jin Kim. (2004). Effect of the presence and difficulty of task on strategy use: An exploratory study. In I, Peter Jordens, \& Eric Kellerman, (Eds.). 42(1), 1-47

Palincsar, A. S., \& Brown, A. L. (1984). Reciprocal teaching of comprehension-fostering and monitoring activities. Cognition and Instruction, 1, 117-175. http://dx.doi.org/10.1207/s1532690xci0102_1

Paris, S. G., Cross, D. R., \& Lipson, M. Y. (1984). Informed strategies for learning: a program to improve children's reading awareness and comprehension. Journal of Educational Psychology, 76(6), 1239-1252

Pavlenko, Aneta, \& Travis, Scott. (2002). Bidirectional transfer. Applied Linguistics, 23(2), 190- 214

Pearson, P. D., \& Fielding, L. (1991). Comprehension instruction. In R. Barr, M. Kamil, P. Mosenthal, \& P. Pearson (Eds.), Handbook of reading research (pp. 815-860). White Plains, NY: Longman.

Pressley, M., Levin, J. R., \& Ghatala, E. S. (1984). Memory strategy monitoring in adults and children. Journal of Verbal Learning Behaviour, 23, 270-288. http://dx.doi.org/10.1016/S0022-5371(84)90181-6

Pressley, M., Beard El-Dinary, P., \& Brown, R. (1992). Skilled and not-so-skilled reading: Good information processing and not-so-good information processing. In M. Pressley, K., Harris, \& J. Guthrie (Eds.), Promoting academic competence and literacy in schools (pp. 91-127). San Diego, CA: Academic Press.

Ross, B. H. (1987). This is like that: The use of earlier problems and the separation of similarity effects. Journal of Experimental Psychology: Learning, Memory, and Cognition, 13, 629-639

Sarig, G. (1987). High-level reading in the first and in the foreign language: Some comparative processes data. In J. Devine, P. Carrell, \& D. E. Eskey (Eds.), Research In Reading in English as Second Language (pp. 105-120). Washington, D.C. : TESOL.

Selinker, L. (1972). Interlanguage. International Review of Applied Linguistics, X(3), 209-231

Sheorey R., \& Mokhtari, K. (2001). Differences in the Metacognitive Awareness of Reading Strategies among Native and Non-native Readers. System, 29(4), 431-449

Taillefer, G., \& Pugh, T. (1998). Strategies for professional reading in $\mathrm{L}_{1}$ and $\mathrm{L}_{2}$. Jornal Of Research in Reading, 21(2), 97-108. http://dx.doi.org/10.1111/1467-9817.00047

Urquart, A., \& Weir, J. C. (1998). Reading in a Second Language: process and product. London Longman.

Table 1. Mean pre-, and post-test scores in English reading test of students with intermediate and advanced level of proficiency of experimental and control groups

\begin{tabular}{|c|c|c|c|c|c|c|}
\hline \multirow[b]{3}{*}{ GROUPS } & \multirow[b]{3}{*}{ PROFICIENCY } & \multicolumn{4}{|c|}{ Groups } & \multirow[t]{3}{*}{ Change } \\
\hline & & \multicolumn{2}{|c|}{ Pre test } & \multicolumn{2}{|c|}{ Post test } & \\
\hline & & Mean & S.D & Mean & S.D & \\
\hline \multirow[t]{3}{*}{ Control } & Intermediate & 13.30 & 2.02 & 13.40 & 2.06 & 0.10 \\
\hline & Advanced & 15.67 & 1.86 & 15.67 & 1.99 & 0.00 \\
\hline & Total & 14.48 & 2.27 & 14.53 & 2.31 & 0.05 \\
\hline \multirow[t]{3}{*}{ Experimental } & Intermediate & 14.00 & 1.70 & 16.57 & 1.83 & 2.57 \\
\hline & Advanced & 16.10 & 1.58 & 18.73 & 1.98 & 2.63 \\
\hline & Total & 15.05 & 1.94 & 17.65 & 2.19 & 2.60 \\
\hline \multirow[t]{3}{*}{ Total } & Intermediate & 13.65 & 1.89 & 14.98 & 2.51 & 1.33 \\
\hline & Advanced & 15.88 & 1.73 & 17.20 & 2.50 & 1.32 \\
\hline & Total & 14.77 & 2.12 & 16.09 & 2.73 & 1.32 \\
\hline
\end{tabular}


Table 2. Mean pre-, and post-test scores in Persian reading test of students with intermediate and advanced level of proficiency of experimental and control groups

\begin{tabular}{|c|c|c|c|c|c|c|}
\hline \multirow[b]{3}{*}{ GROUPS } & \multirow[b]{3}{*}{ PROFICIENCY } & \multicolumn{4}{|c|}{ Groups } & \multirow{3}{*}{ Change } \\
\hline & & \multicolumn{2}{|c|}{ Pre test } & \multicolumn{2}{|c|}{ Post test } & \\
\hline & & Mean & S.D & Mean & S.D & \\
\hline \multirow[t]{3}{*}{ Control } & Intermediate & 14.43 & 1.57 & 14.53 & 1.70 & 0.10 \\
\hline & Advanced & 16.93 & 2.08 & 17.03 & 2.11 & 0.10 \\
\hline & Total & 15.68 & 2.22 & 15.78 & 2.28 & 0.10 \\
\hline \multirow[t]{3}{*}{ Experimental } & Intermediate & 14.53 & 1.46 & 17.10 & 1.45 & 2.57 \\
\hline & Advanced & 17.20 & 2.09 & 20.27 & 2.43 & 3.07 \\
\hline & Total & 15.87 & 2.24 & 18.68 & 2.55 & 2.81 \\
\hline \multirow[t]{3}{*}{ Total } & Intermediate & 14.48 & 1.50 & 15.82 & 2.03 & 1.34 \\
\hline & Advanced & 17.07 & 2.07 & 18.65 & 2.79 & 1.58 \\
\hline & Total & 15.78 & 2.22 & 17.23 & 2.81 & 1.45 \\
\hline
\end{tabular}

Table 3. Results of repeated measure ANOVA for mean pre-, and post-test scores in English reading test of students with intermediate and advanced level of proficiency of experimental and control groups

\begin{tabular}{|c|c|c|c|c|c|}
\hline Source of variation & $\begin{array}{c}\text { Sum of } \\
\text { Squares }\end{array}$ & df & $\begin{array}{c}\text { Mean } \\
\text { Square }\end{array}$ & F & Sig. \\
\hline Change & 105.338 & 1 & 105.338 & 309.215 & .000 \\
\hline Change x Group & 97.538 & 1 & 97.538 & 286.318 & .000 \\
\hline Change x Proficiency & .004 & 1 & .004 & .012 & .912 \\
\hline Change x Group x Proficiency & .104 & 1 & .104 & .306 & .581 \\
\hline Error (Change) & 39.517 & 116 & .341 & & \\
\hline
\end{tabular}

Table 4. Results of repeated measure ANOVA for mean pre-, and post-test scores in Persian reading test of students with intermediate and advanced level of proficiency of experimental and control groups

\begin{tabular}{|c|c|c|c|c|c|}
\hline Source of variation & $\begin{array}{c}\text { Sum of } \\
\text { Squares }\end{array}$ & df & Mean Square & F & Sig. \\
\hline Change & 127.604 & 1 & 127.604 & 504.903 & .000 \\
\hline Change x Group & 110.704 & 1 & 110.704 & 438.034 & .000 \\
\hline Change x Proficiency & .938 & 1 & .938 & 3.709 & .057 \\
\hline Change x Group x Proficiency & .938 & 1 & .938 & 3.709 & .057 \\
\hline Error (Change) & 29.317 & 116 & .253 & & \\
\hline
\end{tabular}


Table 5. Mean pre-, and post-test scores in English cognitive and metacognitive reading strategies questionnaire of students with intermediate and advanced level of proficiency of experimental and control groups

\begin{tabular}{|c|c|c|c|c|c|c|}
\hline \multirow[b]{3}{*}{ GROUPS } & \multirow[b]{3}{*}{ PROFICIENCY } & \multicolumn{4}{|c|}{ Groups } & \multirow{3}{*}{ Change } \\
\hline & & \multicolumn{2}{|c|}{ Pre test } & \multicolumn{2}{|c|}{ Post test } & \\
\hline & & Mean & S.D & Mean & S.D & \\
\hline \multirow[t]{3}{*}{ Control } & Intermediate & 40.57 & 11.24 & 42.17 & 12.03 & 1.60 \\
\hline & Advanced & 47.17 & 8.47 & 49.77 & 8.41 & 2.60 \\
\hline & Total & 43.87 & 10.41 & 45.97 & 10.98 & 2.10 \\
\hline \multirow[t]{3}{*}{ Experimental } & Intermediate & 43.00 & 6.53 & 104.63 & 4.71 & 61.63 \\
\hline & Advanced & 46.83 & 4.81 & 111.60 & 6.06 & 64.77 \\
\hline & Total & 44.92 & 6.01 & 108.12 & 6.43 & 63.20 \\
\hline \multirow[t]{3}{*}{ Total } & Intermediate & 41.78 & 9.20 & 73.40 & 32.77 & 31.62 \\
\hline & Advanced & 47.00 & 6.83 & 80.68 & 32.01 & 33.68 \\
\hline & Total & 44.39 & 8.48 & 77.04 & 32.47 & 32.65 \\
\hline
\end{tabular}

Table 6. Mean pre-, and post-test scores in Persian cognitive and metacognitive reading strategies questionnaire of students with intermediate and advanced level of proficiency of experimental and control groups

\begin{tabular}{|c|c|c|c|c|c|c|}
\hline \multirow[b]{3}{*}{ ROUPS } & \multirow[b]{3}{*}{ PROFICIENCY } & \multicolumn{4}{|c|}{ Groups } & \multirow[t]{3}{*}{ Change } \\
\hline & & \multicolumn{2}{|c|}{ Pre test } & \multicolumn{2}{|c|}{ Post test } & \\
\hline & & Mean & S.D & Mean & S.D & \\
\hline \multirow[t]{3}{*}{ Control } & Intermediate & 43.67 & 9.59 & 45.50 & 10.16 & 1.83 \\
\hline & Advanced & 50.73 & 7.46 & 52.57 & 7.27 & 1.84 \\
\hline & Total & 47.20 & 9.23 & 49.03 & 9.45 & 1.83 \\
\hline \multirow[t]{3}{*}{ Experimental } & Intermediate & 43.43 & 8.53 & 103.13 & 4.31 & 59.70 \\
\hline & Advanced & 47.70 & 4.10 & 105.67 & 5.85 & 57.97 \\
\hline & Total & 45.57 & 6.98 & 104.40 & 5.25 & 58.83 \\
\hline \multirow[t]{3}{*}{ Total } & Intermediate & 43.55 & 9.00 & 74.32 & 30.07 & 30.77 \\
\hline & Advanced & 49.22 & 6.16 & 79.12 & 27.56 & 29.90 \\
\hline & Total & 46.38 & 8.19 & 76.72 & 28.82 & 30.34 \\
\hline
\end{tabular}

Table 7. Results of repeated measure ANOVA for mean pre-, and post-test scores in English cognitive and metacognitive reading strategies questionnaire of students with intermediate and advanced level of proficiency of experimental and control groups

\begin{tabular}{|c|c|c|c|c|c|}
\hline Source of variation & $\begin{array}{c}\text { Sum of } \\
\text { Squares }\end{array}$ & df & Mean Square & F & Sig. \\
\hline Change & 63961.350 & 1 & 63961.350 & 3337.064 & .000 \\
\hline Change x Group & 55998.150 & 1 & 55998.150 & 2921.599 & .000 \\
\hline Change x Proficiency & 64.067 & 1 & 64.067 & 3.343 & .070 \\
\hline Change x Group x Proficiency & 17.067 & 1 & 17.067 & .890 & .347 \\
\hline Error (Change) & 2223.367 & 116 & 19.167 & & \\
\hline
\end{tabular}


Table 8. Results of repeated measure ANOVA for mean pre-, and post-test scores in cognitive and metacognitive reading strategies questionnaire of students with intermediate and advanced level of proficiency of experimental and control groups

\begin{tabular}{|c|c|c|c|c|c|}
\hline Source of variation & Sum of Squares & df & Mean Square & F & Sig. \\
\hline Change & 55206.667 & 1 & 55206.667 & 3872.278 & .000 \\
\hline Change x Group & 48735.000 & 1 & 48735.000 & 3418.346 & .000 \\
\hline Change x Proficiency & 11.267 & 1 & 11.267 & .790 & .376 \\
\hline Change x Group x Proficiency & 11.267 & 1 & 11.267 & .790 & .376 \\
\hline Error (Change) & 1653.800 & 116 & 14.257 & & \\
\hline
\end{tabular}

